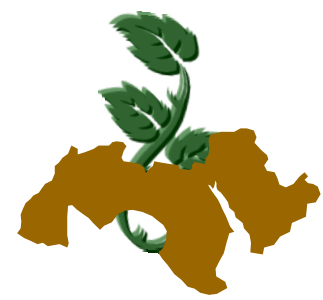

\title{
EVALUATION OF SOME WATER TRAPS FOR CONTROLLING HAIRY ROSE BEETLE ADULTS, TROPINOTA SQUALIDA SCOP. (COLEOPTERA: SCARABAEIDAE)
}

\author{
Hanafy ${ }^{1}$, H.E.M. \\ 1- Department of Plant Protection, Faculty of Agriculture, Ain Shams University, Shoubra \\ El-Kheima, Cairo, Egypt
}

Keywords: Evaluation, Hairy rose beetle, Water traps, Tropinota squalida, Control

\begin{abstract}
Different coloured plastic buckets (yellow, red, blue and white), filled with water were used as traps for adults of Tropinota squalida Scop. in apple orchards at El-Khatatba (El-Behaira Governorate) during seasons 2005 and 2006. The general mean numbers of adults/ trap were $6.0,8.1$, 14.4 and 24.1 in 2005 and 4.7, 6.7, 10.5 and 18.7 in 2006 seasons for white, red, yellow and blue traps, respectively. The general means for trap efficiency (two seasons) were 9.8, 13.7, 23.2 and 39.3 for white, red, yellow and blue traps, respectively. Two groups of white plastic cups, group filled with blue water solution and another group filled with water were used as traps and slung in apple trees. The general mean numbers of adults/trap were $8.1 \& 7.5$ for blue water solution and $5.8 \& 5.2$ for water traps during 2005 and 2006 , respectively. The general means of trap efficiency (two seasons) were 36.8 and $25.9 \%$ for the above mentioned traps, respectively.
\end{abstract}

\section{INTRODUCTION}

The hairy rose beetle, Tropinota squalida Scop.(Coleoptera: Scarabaeidae) attacks ornamental plants in Egypt, but its population was found to be below the economic threshold in valley lands till 1976, therefore no serious problem was foreseen (Alfieri, 1976). In recent years, its population caused great damage to various plantations and flowers of different crops especially in apple or- chards (Ali and Ibrahim, 1988). In newly reclaimed areas, $T$. squalida beetles were attracted to wide range of plant flowers, causing considerable damage to them. The flowers of field crops, i.e. broad bean, lupine and wheat; fruit trees, i.e. apple, pear, citrus; vegetables, i.e. cabbage, radish, turnip and rocket and weeds between wild mustard and wild radish are severely attacked by this pest (Sherief et al 2003). Adults of T. squalida also feed on grape buds and young shoots, preventing or deforming growth of fruit and reducing crop yield (Ortu et al 2001).

Using the water traps for the control of $T$. squalida adults started to decrease slowly in the last 15 years in such areas (Sherief et al 2003). Traps may play an important role in suppressing the population density and reduce injuries of $T$. squalida, especially if it was distributed in the early season (Sherief $\boldsymbol{e t}$ al 2003). Monitoring and mass trapping of insect populations using traps could have a key role in integrated pest management programmes (Adverson et al 1977 and Campion, 1976).

Aim of the present work is to evaluate the effectiveness of water traps of different colours for the control of $T$. squalida adults in apple orchards during the flowering season.

\section{MATERIALS AND METHODS}

Two experiments were carried out at ElKhatatba (El-Behaira Governorate) in apple orchard of private sector during two successive flowering seasons, 2005 and 2006. The first experiment was concerned with studying the efficiency of different colours of buckets for trapping $T$. 
squalida adults. The second was to evaluate the effect of water colour on attracting $T$. squalida adults.

\section{Colours of plastic buckets}

Yellow, blue, red and white of plastic buckets, measuring $43 \mathrm{~cm}$ in diameter and $12 \mathrm{~cm}$ in height were filled with clear water and randomly distributed under apple trees. Sixty coloured buckets/ feddan were used, each colour contains 15 traps. On weekly bases, the buckets were investigated and the number of trapped T. squalida was counted throughout the period extended from February till the end of March.

\section{White plastic cups}

Two groups of white plastic cups measuring 12 $\mathrm{cm}$ in diameter and $8 \mathrm{~cm}$ in height were slung in apple orchards as traps for adults (one cup/ tree). The first group (45 cups) filled with clear water and the second group (45 cups) filled with blue coloured water by adding copper sulphate to water. Cups were randomly distributed. T. squalida adults were collected weekly and counted. The efficiency of the traps was estimated by using the following formula:

$$
\% \text { Trap efficiency }=\frac{A}{B+C} \times 100
$$

A: Mean No. of adults in each trap

B: Total mean No. of adults caught in all traps

C: Mean No. of adults/tree

\section{RESULTS AND DISCUSSION}

\section{Coloured plastic buckets filled with water}

As shown in Table (1), the mean number of caught $T$. squalida in the first season (2005) was highly significantly higher than caught in the second season (2006). This was common for any colour of experimental buckets. Means of 14.4, 8.1, 24.1 and 6.0 adults/ trap in the first season and $10.5,6.7,18.7$ and 4.7 adults/ trap in the second season were recorded after using yellow, red,blue and white traps, respectively. This means that the most attractive colour for $T$. squalida adults were blue, followed by yellow and red colours. White coloured traps were less attractive for this insect, as the least number of adults were caught. This was common in both experimental years.
The population of $T$. squalida adults caught in different coloured buckets traps filled with water was weekly counted from the beginning of February till the end of March in the apple orchard. Generally the population started at low level, gradually increased to reach the maximum number in the first week of March of both experimentally years, then the population gradually decreased to reach the minimum at the end of season, i.e., in the fourth week in the March.

Maximum mean numbers of 44.9, 26.1, 15.5 and 12.1 adults/trap on March 4, 2005 and 32.7, 19.2, 13.3 and 8.9 adults/trap on March 3, 2006 were recorded in blue, yellow, red and white traps, respectively.

Statistical analysis showed a highly significant difference between the four coloured traps during 2005 and 2006. The best colour trap for attracting the adults of $T$. squalida was the blue followed by yellow traps. Results are in agreement with the findings of El-Deeb (1992); Ali (1993); Hydar et $\boldsymbol{a l}$ (1993) and Sherief $\boldsymbol{e t}$ al (2004) who found that the blue water traps attracted considerable numbers of $T$. squalida adults than the other tested coloures. Schmera et al (2004) found that adults of Epicometis hirta (Scarabaeidae) were attracted to yellow, white or light blue colours with no significant differences between colours.

From the present results, it could be concluded that the use of such colours in trapping system is a safe method for controlling adults of $T$. squalida in the apple orchards in Egypt.

\section{White plastic cups}

Data in Table (2) showed that the minimum and maximum mean numbers of $T$. squalida adults/ trap were $3.5 \& 13.1$ and $2.6 \& 12.2$ for white cups filled with blue water solution and those filled with water only, respectively during season 2005. The general mean numbers of adults/trap were 8.1 and 5.8 for the above mentioned traps, respectively.

On the other hand, during season 2006, the lower and highly means numbers of adults/ trap were $2.8 \& 12.8$ and $2.1 \& 11.6$ for white cups filled with blue water solution and water, respectively. The general means numbers of adults/ trap were 7.5 and 5.2 for white plastic cups filled with blue water solution and water, respectively. The statistical analysis showed a highly significant difference between the two traps. 
The efficiency of blue coloured buckets was highly effective for the attraction of $T$. squalida adults giving 38.7 and $39.8 \%$ in 2005 and 2006 flowering seasons, respectively. This was followed by the use of yellow traps 23.1 and $22.3 \%$ during 2005 and 2006, respectively. Meanwhile, efficiency for red and white traps recorded 13.0 \& $14.3 \%$ and $9.6 \% 10.0 \%$ during 2005 and 2006, respectively. The general means of trap efficiency for the two seasons were 9.8, 13.7, 23.2 and $39.3 \%$ for white, red, yellow and blue traps, respectively. Sherief et al (2003) found that the efficiency of blue pan water and blue funnel traps were 72.48 and $13.44 \%$ (apple), $58.08 \%, 22.37 \%$ (pear), 83.73 and $4.48 \%$ (navel orange) and 86.84 and $5.98 \%$ (strawberry), respectively.

Data presented in Table (3) pointed that the trap efficiency values were 34.3 \& $39.3 \%$ for white plastic cups filled with blue water solution and $24.6 \& 27.2$ for white cups filled with water during 2005 and 2006, respectively. The general means of trap efficiency for two seasons were 36.8 and $25.9 \%$ for the above mentioned traps, respectively.

\section{REFERENCES}

Alfieri, A. (1976). The coleoptera of Egypt. Memo. Bull. Soc. Ent. Egypt, p. 361.

Ali, M.A. (1993). Influence of trap colours and placement on captures of the hairy rose beetle, Tropinota squalida Scop. (Coleoptera: Scarabaeidae). Insect science and its Application, 14(2): 215 - 219.

Ali, M.A. and I.L. Ibrahim (1988). Prelimenary study on occurrence and abundance of Tropinota squalida Scop. (Coleoptera: Scarabaeidae) infesting certain ornamental plants and fruit crops. AlAzhar J. Agric. Res., 9: 1-14.
Adverson, D.R.; J.N. All and R.W. Mathews (1977). Response of leaf worms and aphids to variously coloured sticky traps. J. Georgia Entomol. Soc., 12(4): 336-410.

Campion, D.G. (1976). A comparison of the catches of moths of the cotton leaf worm S. littoralis (Boisd.) in light traps and pheromone traps. Crop Misc. Rep., 21: 1-4.

El-Deeb, M.A. (1992). Biological and ecological studies on Tropinota Squalida Scop. at Sharkia Governorate. Zagazig J. Agric. Res., 19(3): 1409 $-1419$.

Hydar, M.F.; M.M. El-Husseini and H. AbouBakr (1993). Coloured water traps for monitoring in apple orchards in the northern parts of Egypt. J.Agric. Res., 71(1): 233 - 240.

Ortu, S.; A. Lentini and M. Acciaro (2001). Some observations on Tropinota squalida (Scop.) infestation in Sardinian vineyards. Bulletin OILB / SROP, 24(7): 113 - 116.

Schemra, D.; M. Toth; M. Subchev; I. Sredkov; I. Szarukan; T. Jermy and A. Szentesi (2004). Importance of visual and chemical cues in the development of an attractant trap for Epicometis (Tropinota) hirta Poda (Coleoptera: Scarabaeidae). Crop Protection, 23(10): 939 - 944.

Sherief, E.A.H.; M.M. El-Zohairy; M.A. ElDeeb and W.M.H. Desuky (2003). Non chemical control methods of Tropinota squalida Scop. Adults (Coleoptera: Scarabaeidae) in the newly reclaimed lands. Egyptian J. Agric. Res., 81(2): 491- 505.

Sherief, E.A.H.; M.M. El-Zohairy and M.A. ElDeeb (2004). Preferred host plant, flowers and trap colours to Tropinota squalida Scop. Adults (Coleoptera: Scarabaeidae). Egyptian J. Agric. Res., 82(4): 1525-1536. 